\title{
Mismatch: University Education and Labor Market Institutions
}

\author{
Ben Ansell and Jane Gingrich \\ Paper for PS Special Issue on Politics of Higher Education. \\ The ECHP and SILC data is used on behalf of contract reference 49/2013-EU-SILC \\ between Jane Gingrich and Eurostat.
}

Higher education around the globe has undergone dramatic 'transformations' over the past few decades, as mass higher education has become a near-universal policy across the industrialised world. However, not all new graduates have entered high-paying, secure jobs. Higher education only produces a 'high skill society' where labor market institutions permit entry by new graduates and offer them wages and employment that match their skills. In this article, we argue that because labor market institutions vary dramatically, in some countries, particularly in Southern Europe, many new graduates are likely to be under-employed and under-paid, potentially producing a widespread growth of political dissatisfaction among these new indignados.

The contributions to this special issue on the comparative politics of higher education emphasize that higher education systems vary dramatically in their reliance on private funds, in their stratification or universalism, and in the ways they accordingly shape and reshape class and race relations in society. And yet, among policymakers, even if the governance and funding structure of higher education remain bones of contention, there is emphatic agreement that mass higher education provision is a desirable policy. This ambition was paramount in the 
European Union's Lisbon Strategy of 2000 which aimed at Europe becoming the most competitive and dynamic knowledge-based economy in the world.' Though declarations of intent from the European Union may not be history's most reliable guide to ensuing policymaking, in this case member governments did appear to be at one with strategies of expanding enrollment, and often funding, for university systems across Europe. This 'massification' of higher education (Trow 1973) has also been apparent over the past several decades in North America, Australia and New Zealand, East Asia - first Japan, then South Korea and Taiwan, and now China - and more generally among upper middle income countries.

What happens to all of these new graduates once they enter the labour market? The study of 'life transitions' has typically been the domain of education sociologists who have provided important data on cross-national trends for graduates (Breen and Jonsson 2005: Shavit et al. 2007). However, many of these works neglect the labour market institutions which govern how employers and the state demand, use, and remunerate skilled workers. Moreover, existing work has not asked how the relative labour market success of skilled workers shapes their attitudes about the economy and politics, even as graduates have verged on a majority of the workforce across the industrialized world.

Fortunately, existing literatures in comparative political economy provide a framework within which to think about and empirically examine the socioeconomic outcomes and preferences of university graduates. Scholars have long emphasized the important role that labour market institutions governing wage bargaining and employment rights have in shaping the distribution of wages (Wallerstein 1999). In addition, countries with large public sectors also tend to have more compressed wage distributions (Iversen and Wren 1998). Broadly then, longstanding institutional differences across countries create stable cross-national pat- 
terns of wage compression. These differences shape the relative prospects of graduates (Ansell and Gingrich 2013), reducing both the downside risk of low wages to graduates but also upside benefits of high wages.

Wage compression is not the only institutional difference facing graduates. Since graduates traditionally entered the professions, restrictions on entry into these professions or impediments to their expansion will also condition how new graduates fare. Existing work in comparative political economy has long noted that restricted entry into jobs in manufacturing has created labor market dualization (Häusermann and Schwander 2012; Rueda 2007). However, there has been less attention paid to barriers to entry in high skilled professions (though see Schwander, Häusermann and Kurer (2014) on 'high skilled outsiders'). In many continental European countries, access to high-paying professions such as public notary is highly restricted and these professions have effectively protected themselves from market entry by rival firms or industries. In such countries, when university enrollment is low, those few graduates in the labour market dominate these professions and receive high wage returns. However, once higher education enrollment expands, professional sectors are unable to absorb these graduates and resist downward pressure on their wages and privileges. This may push graduates into typically 'non-graduate' jobs.

These institutional differences - wage compression and professional 'protectionism' - mean that the universal story of rising higher education enrollment will have strikingly different labor market outcomes across the developed world. In some countries, the graduate wage premium will continue to rise even as a majority of citizens attend college. According to data we analysed from the European Community Household Panel (ECHP) and the EU Statistics on Income and Living Conditions (EU-SILC), the gross monthly wage premium for graduates rose by 
ten percent between 1993 and 2012 in the UK, Ireland, Holland and a number of other European countries. In others graduation rates rose but the graduate wage premium has remained stable or declined, for example France, Portugal, Spain, and Sweden. In the case of the Scandinavian countries such as Sweden, this is not because graduates cannot find 'graduate-level' jobs but because wage compression prevents soar-away salaries for the best paid graduates. However, in the case of other countries - typically Southern European - where professions remain protected but higher education expands, the problem of 'skill mismatch' may be increasingly common.

'Mismatch' occurs when graduates enter jobs that have not been traditionally associated with holding a university degree. Of course in a few cases, for example agriculture, new graduates may actually improve productivity in the job. However, in many cases, mismatch happens when graduates enter low-skill employment that neither uses their skill-set nor pays them a graduate premium - a classic example would be university graduates working in retail jobs. In these cases, for example Italy and Spain, a generation of under-employed, or at least under-remunerated, young graduates may emerge. Social investment policies of mass higher education are not creating 'competitive and dynamic knowledgebased economies' to requote the Lisbon Agenda. They are creating the conditions for mass discontent - for indignados and populism - often at odds with the European project.

While space prevents us from a more detailed analysis of how mismatch plays out economically and in terms of political preferences, we present a couple of graphs that show the extent of the problem across Europe. Here we draw on data from the ECHP and the EU-SILC datasets mentioned above. We are able to sort working-age citizens across Europe into 'jobs' - defined as an occupation-sector 
combination. This follows the technique used in Goos, Manning and Salomons (2009) to measure changes in job 'quality' by occupation-sector combination. Doing so permits us to move beyond accounts that identify solely occupation (Rehm 2011) or sector (Walter 2010) to be able to distinguish among different types of workers within sectors, and among similar workers across sectors. We then define a 'mismatched' individual as someone who is in a job where fewer than sixty percent of workers have a degree (defined across all Europe as a whole). Obviously this threshold is somewhat arbitrary and misses variation within occupation-sector combinations. But as our figures show the mismatch variable defined this way does vary dramatically across Europe and is broadly associated with lower wages compared to non-mismatched individuals.

Figure 1: Cross-country Patterns of Graduate Stock and Mismatch

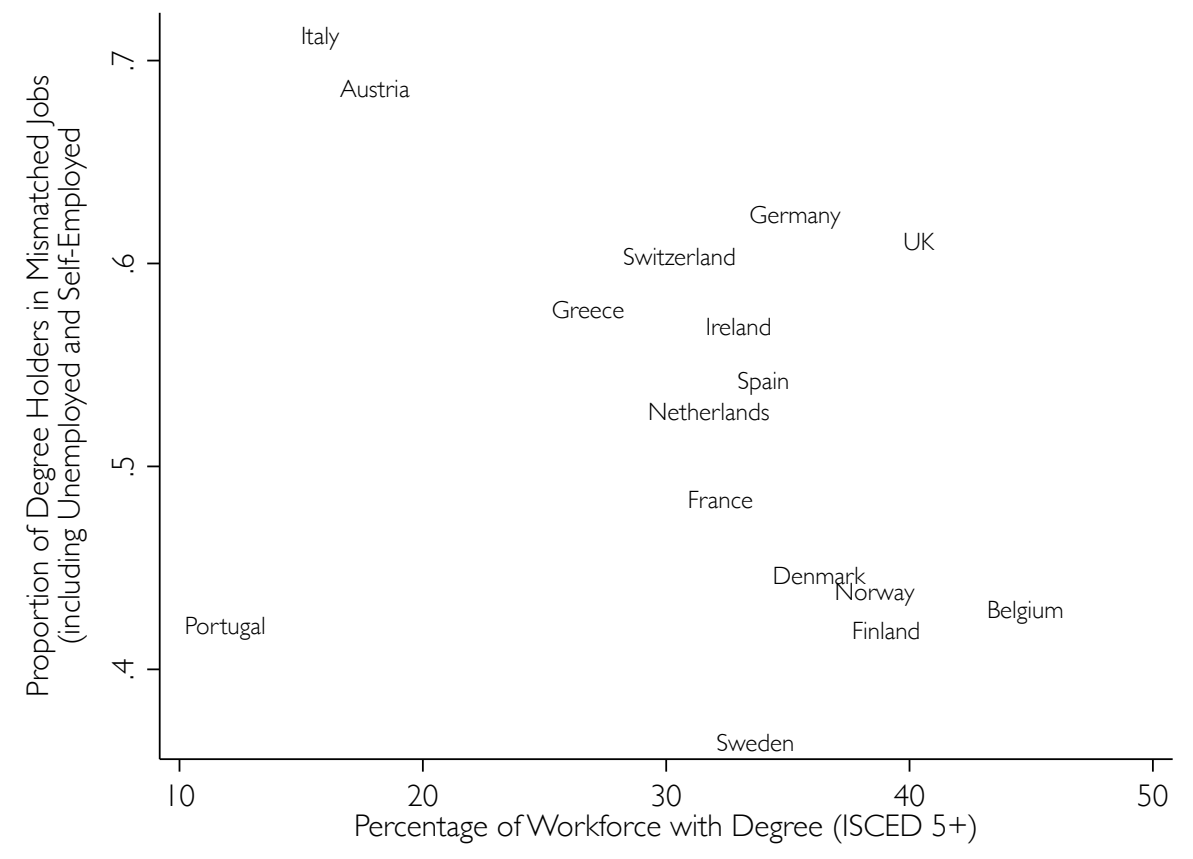

Figure 1 shows the country average proportion of degree-holders who are ei- 
ther in mismatched jobs or self- or unemployed (which we view as other forms of mismatch, though the patterns look similar if we exclude these groups), plotted by the proportion of the workforce who hold a degree for the period 1993 to 2012. Where graduation rates remain very low, as in Portugal, mismatch is unsurprisingly also low. However, beyond Portugal there is a clear negative correlation in many countries such as Italy, Austria and Greece, new graduates are often failing to enter graduate level employment, either by entering non-graduate jobs or ending up self-employed or unemployed.

Mismatch also appears common in countries with longstanding traditions in vocational training such as Switzerland and Germany (Busemeyer 2014). In these examples what might appear to be mismatch could be less problematic - graduates entering fields with a lower presence of graduates both with traditionally high skill levels because of vocational training. The Southern European cases are more problematic since such systems are absent so when graduates enter non-graduate employment it is typically low-skill work. By contrast in the Scandinavian countries, even though graduation rates are high, the majority of graduates do work in graduate positions. Any claims about causality must be cautious - Scandinavia may have expanded higher education early because its labor market institutions could absorb higher-skilled workers more effectively. Still, the 'shock' of policy diffusion of higher education expansion to countries with a previously minimal higher education effort such as Greece, Italy and Spain was at least partly driven by EU-level commitments, rather than labor market structure.

Figure 2 shows that in most countries mismatch has a negative impact on income, defined as gross monthly wages relative to the country-year mean. In some countries such as Spain, even though mismatch may only be at moderate aggregate levels, it has dramatic negative effects on wages. By contrast in many of the 
Figure 2: Skill Mismatch and Relative Gross Monthly Wages

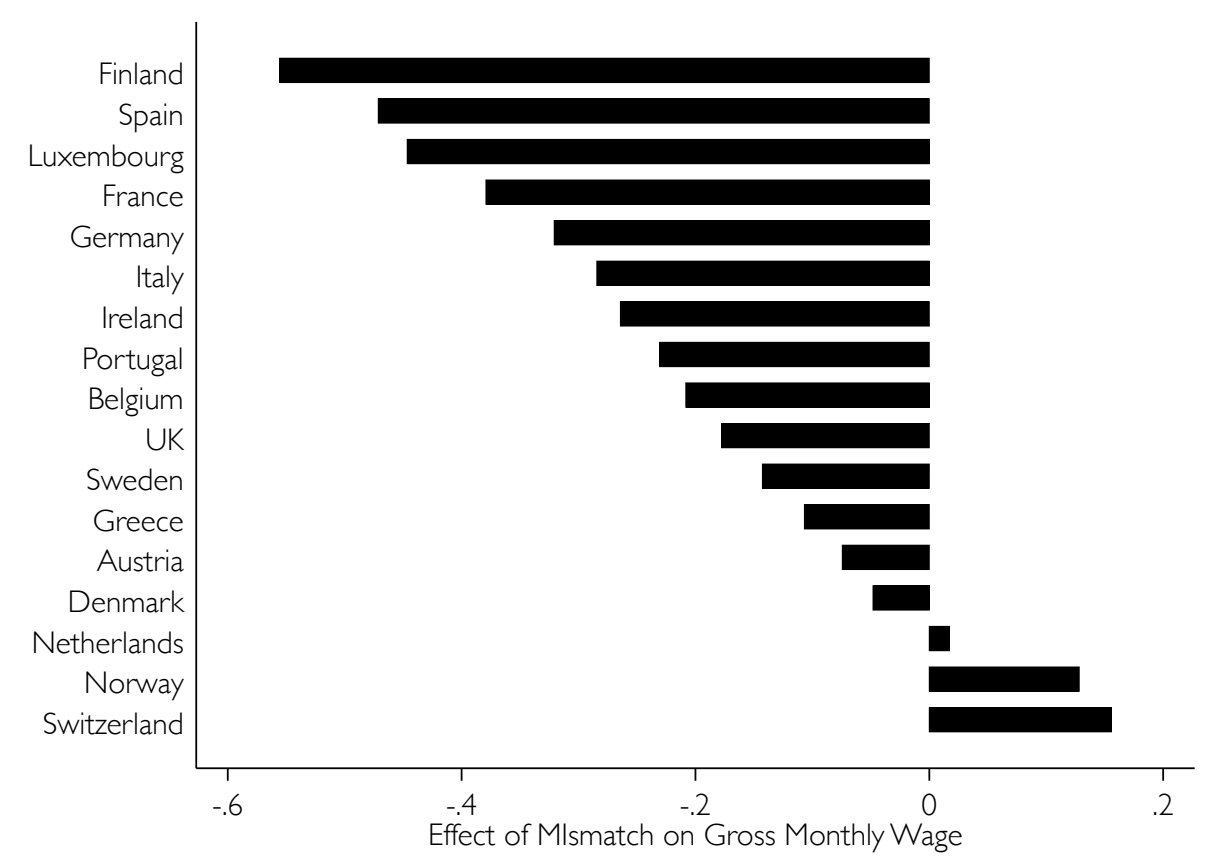

Coefficients on skill mismatch variable taken from regression of self-reported income from gross monthly wages on demographic characteristics using ECHP-SILC data from 1993 to 2012. 
Scandinavian countries, the effect of mismatch is minimal (or even positive), even though mismatch is rarer.

Put simply, in some countries, particularly those in Southern Europe, earning a university degree exposes young people to high labour market risks of ending up in a lower paid non-graduate jobs, whereas in others, particularly Scandinavia, these risks are far lower. The implications of this kind of 'mismatch' may not simply be economic. Witness for example the indignados movement in Spain and the growing support for anti-system parties in Italy and Greece. Ansell and Gingrich (2017) demonstrate that mismatched individuals have lower trust in politicians, more antipathy towards migrants and are less likely to vote than other graduates, using data drawn from the European Social Survey.

Thus, social investment policies have sharply different outcomes, both economic and political, across countries, depending on how the labor market is structured. Mass higher education is not an obvious panacea for all - its beneficial economic effects are highly dependent in prevailing institutions. Of course the benefits to higher education should not solely be judged by the labor market. Perhaps a vigorous democracy depends on an educated citizenry and the international cultural and educational relations inspired by higher education. However, if 'mismatched graduates' themselves lose trust in the political system and the wider European project, even such more diffuse benefits may be under threat.

\section{References}

Ansell, Ben and Jane Gingrich. 2013. A tale of two trilemmas: varieties of higher education and the service economy. Oxford University Press p. 195.

Ansell, Ben W and Jane R Gingrich. 2017. Skills in Demand? In Political Competi- 
tion and Voter/Party Alignment in Times of Welfare State Transformation, ed. Philip Manow, Bruno Palier and Hanna Schwander. Oxford University Press.

Breen, Richard and Jan O Jonsson. 2005. "Inequality of opportunity in comparative perspective: Recent research on educational attainment and social mobility." Annual review of sociology pp. 223-243.

Busemeyer, Marius R. 2014. Skills and inequality: Partisan politics and the political economy of education reforms in western welfare states. Cambridge University Press.

Goos, Maarten, Alan Manning and Anna Salomons. 2009. "Job polarization in Europe." The American Economic Review pp. 58-63.

Häusermann, Silja and Hanna Schwander. 2012. "Varieties of dualization? Labor market segmentation and insider outsider divides across regimes." The age of dualization: The changing face of inequality in deindustrializing societies pp. 27-51.

Iversen, Torben and Anne Wren. 1998. “Equality, employment, and budgetary restraint: the trilemma of the service economy." World politics 50(04):507-546.

Rehm, Philipp. 2011. “Social policy by popular demand." World Politics 63(02):271299.

Rueda, David. 2007. Social Democracy Inside Out: Partisanship and Labor Market Policy in Advanced Industrialized Democracies. Oxford University Press.

Schwander, Hanna, Silja Häusermann and Thomas Kurer. 2014. “High-skilled outsiders? Labor market vulnerability, education and welfare state preferences." Socio-Economic Review p. mwu026.

Shavit, Yossi et al. 2007. Stratification in higher education: A comparative study. Stanford University Press. 
Trow, Martin. 1973. Problems in the Transition from Elite to Mass Higher Education. Technical report University of California, Berkeley.

Wallerstein, Michael. 1999. "Wage-setting institutions and pay inequality in advanced industrial societies." American Journal of Political Science pp. 649-680.

Walter, Stefanie. 2010. "Globalization and the welfare state: Testing the microfoundations of the compensation hypothesis." International Studies Quarterly 54(2):403-426. 